\title{
Impacts of enhanced nitrogen deposition and soil acidification on biomass production and nitrogen leaching in Chinese fir plantations
}

\author{
Juan A. Blanco ${ }^{\text {a,b }}$, Xiaohua Wei ${ }^{\text {c,d }}$, Hong Jiang ${ }^{\text {b,e* }}$, Cheng-Yue Jie ${ }^{b}$, Zan-Hong Xin ${ }^{\text {b }}$ \\ ${ }^{a}$ Department of Forest Science, University of British Columbia, 2424 Main Mall, Vancouver, B.C., V6T \\ 1Z4, Canada; Tel: (+1) 604-822-8876; Fax: (+1) 604-822-9133.
}
${ }^{\mathrm{b}}$ State Key Laboratory of Subtropical Forest Science \& Zhejiang Provincial Key Laboratory of Carbon Cycling in Forest Ecosystems and Carbon Sequestration, Zhejiang Agriculture and Forestry University, Hangzhou, 311300, Zhejiang, China, Tel: (+86) 571-63748781; Fax (+86) 571-63740030.

${ }^{\mathrm{c}}$ Department of Earth and Environmental Sciences, University of British Columbia, 3333 University Way, Kelowna, B.C., V1V 1V7, Canada; Tel (+1) 250-807-8750; Fax (+1) 250-807-8005.

${ }^{\mathrm{d}}$ College of Forestry, Jiangxi Agriculture University, Nanchang, China 330045

\footnotetext{
${ }^{\mathrm{e}}$ International Institute for Earth System Science, Nanjing University, Nanjing 210093, Jiangsu, China
}

Emails: 
Juan A. Blanco: juan.blanco@ubc.ca

Xiaohua Wei: adam.wei@ubc.ca

Hong Jiang: jianghong_china@ hotmail.com*Corresponding author

Cheng-Yue Jie: iamjcy@126.com

Zan-Hong Xin: zanhoon812@yahoo.com.cn

\section{Abstract}

Atmospheric pollution levels in China are increasing quickly. Experience from other polluted regions shows that tree growth could be affected, but long-term effects of $\mathrm{N}$ deposition and soil acidification on Chinese forests remain mostly unknown. Soil acidification and $\mathrm{N}$ deposition were simulated for Chinese fir plantations in Southeast China. A factorial experiment combined four levels of rain pHs (2.5, 4.0, 5.6 and 7.0), four $\mathrm{N}$ deposition rates $\left(1,7.5,15\right.$ and $\left.30 \mathrm{~kg} \mathrm{~N} \mathrm{ha}^{-1} \mathrm{y}^{-1}\right)$ and two site qualities (poor and rich sites), managed for 3 consecutive 20 -year rotations. Results indicate atmospheric pollution effects are not immediate, but after 1 to 2 rotations soil acidification effects could reduce ecosystem C pools significantly (-25\% and $-11 \%$ in poor and rich sites, respectively). $\mathrm{N}$ deposition rates above $15 \mathrm{~kg} \mathrm{~N} \mathrm{ha}^{-1} \mathrm{y}^{-1}$ could offset some of the negative effects of soil acidification and led to more ecosystem $\mathrm{C}$ (19 and $28 \mathrm{Mg} \mathrm{Cha}^{-1}$ more in poor and rich sites than in low $\mathrm{N}$ deposition). However, at high $\mathrm{N}$ deposition rates $\left(>15 \mathrm{~kg} \mathrm{~N} \mathrm{ha}^{-1}\right.$ $\mathrm{y}^{-1}$ ), $\mathrm{N}$ leaching losses could greatly increase, reaching $75 \mathrm{~kg} \mathrm{~N} \mathrm{ha}^{-1} \mathrm{y}^{-1}$. Moderate $\mathrm{N}$ deposition could increase tree biomass production and soil organic mass, resulting in increased ecosystem $\mathrm{C}$, but these gains could be associated to important $\mathrm{N}$ leaching. Atmospheric pollution could also result in the longterm in nutrient imbalances and additional ecological issues (i.e. biodiversity loss, eutrophication, etc.) not studied here.

Key words: N deposition, Cunninghamia lanceolata, FORECAST model, sustainable forest management, atmospheric pollution, $\mathrm{C}$ sequestration. 


\section{Introduction}

Concern about the possible effects of acid rain in China emerged in the late 1970s (Fan and Wang 2000), with the first reports appearing in the international literature in the 1980s (Zhao and Sun 1986). In the southern part of the Yangtze River basin precipitation since the late 1980s has been found to have average pH between 3.5 and 4.8 (An et al. 2001). As a consequence, forest soils in southern China have become more acidic during the last decades (Fan and Wang 2000). A major cause of acid rain in China is the release of $\mathrm{SO}_{2}$ from the extensive combustion of coal, which accounted for $69 \%$ of the energy production in 2006. Although the Chinese authorities have set regulations to reduce acidic pollution from the energy sector, based on the increasing trends of energy consumption in the future and the high investment needed for desulfurization, it is expected that the severity and area affected by acid deposition in China will continue to increase (Zhao et al. 2009).

Southern China also has some of the highest nitrogen deposition rates in the world, with rates similar to central Europe and eastern North America (Du et al. 2008). Usual values range from $7 \mathrm{~kg} \mathrm{~N} \mathrm{ha}^{-1} \mathrm{y}^{-1}$ in rural areas to $30 \mathrm{~kg} \mathrm{~N} \mathrm{ha}^{-1} \mathrm{y}^{-1}$ in industrial areas, reaching in particular locations $50 \mathrm{~kg} \mathrm{~N} \mathrm{ha}^{-1} \mathrm{y}^{-1}$ and above (Chen and Mulder 2007). The majority of anthropogenic $\mathrm{NH}_{3}$ in China is emitted from industrial activities, $\mathrm{N}$ fertilizers and animal excreta (Zhang et al. 2010), whereas $\mathrm{NO}_{\mathrm{x}}$ emissions are derived mainly from fossil fuel combustion processes including power plants, transportation and industry (Streets and Waldhoff 2000). By 2005, ammonia emissions had doubled, and $\mathrm{NO}_{\mathrm{x}}$ emissions had increased by a factor of 4 compared to 1980 (Zhao et al. 2009). The Chinese authorities have established a plan to reduce $\mathrm{N}$ emissions, but the quick increase in the number of vehicles and the intensification of agricultural and industrial activities will likely increase the levels of $\mathrm{N}$ deposition in the near future (Larssen et al. 2006). If this trend continues, $\mathrm{N}$ deposition could make a larger contribution to acid rain than sulfuric deposition in China in the near future (Liu et al. 2010a).

Nitrogen deposition can increase cation leaching from forest soils, decrease soil buffering capacity, and 
contribute to soil acidity in two ways: direct effects of nitric acid, and nitrification of ammonia in soil, which generates hydrogen ions. Soil acidification and $\mathrm{N}$ deposition could have important implications for forest productivity. Reductions in growth at stand-level due to acid rain in heavily polluted areas have been reported, first in central Europe and east North America and nowadays also in southeast China (Bäck et al. 1995). However, clear evidences of physiological damage at tree or leaf level are limited to lab experiments or sites with severe defoliation (Kennedy 1992). On the other hand, moderate N deposition could enhance tree grow but increase tree mortality, nutrient leaching and eutrophication of forest streams (Liu et al. 2010b, Thomas et al. 2010).

It has been reported that increasing $\mathrm{N}$ availability by $\mathrm{N}$ deposition has outweighed soil acidification caused by acid rain in some European (Emmett et al. 1998) and North American forests (Thomas et al. 2010), but little is known about Asian forests (Fujimaki et al. 2009). Also, acidification impacts are not immediate, and it may be possible that increased $\mathrm{N}$ availability may not necessarily offset acidification impacts in the long-term. Solberg et al. (2004) estimated that forest growth in Norway under anthropogenic $\mathrm{N}$ deposition could increase by $25 \%$ in spite of being accompanied by acid rain. However, most of the research done on the effects of atmospheric pollution on tree growth has been carried out in western and northern Europe or eastern U.S.A., regions with temperate climates, temperate tree species, and a history of gradual increase in atmospheric pollution following a century of industrial and urban development. These studies are not directly transferable to south-eastern Chinese forests as they are composed by sub-tropical fast-growing species growing in a monsoon climate and experiencing a short but intense history of atmospheric pollution. These facts could produce interactions between trees, plants and soil different to the ones reported for previous regions, justifying the need for research specific to Chinese forests.

In spite of the important potential effects of acidic pollution in forests, little information exists on its long- 
term consequences on forest ecosystems in China or in other subtropical and monsoon regions (Larssen et al. 2006). Furthermore, the usual short-term experimental data available in China and the lack of studies on the interactions with other factors have restricted conclusions on long-term consequences of acid and $\mathrm{N}$ pollution at ecosystem level (Du et al. 2008). Therefore, it is necessary to study the interaction of both types of ecological effects of pollution ( $\mathrm{N}$ deposition and soil acidification) and their combined effects on Chinese forests. This is especially important in SE China, where the Yangtze basin is one of the most important areas of timber production in the country, especially with Chinese fir (Cunninghamia lanceolata (Lamb.) Hook.) plantations.

Several biogeochemical models have been used before to estimate the impacts of atmospheric pollution (Reinds et al. 2009, Ito 2007, Posch and Reinds 2009; among others), but these models only have a simplified representation of vegetation (Bonten et al. 2009) and therefore they are not suitable to explore the interactions between $\mathrm{N}$ deposition, soil acidification and forest management. On the other hand, several process models have been developed to simulate the effects of acid rain in forest ecosystems (i.e. Belanger et al. 2002, Hartman et al. 2007), but they are very data-intensive, which makes them unsuitable for forest management applications (Kimmins et al. 2008). As a consequence, one of the best tools to study these impacts are ecosystem-level forest management models. Among them, the FORECAST model (Kimmins et al. 1999) has been successfully tested and used before in several types of forest (Blanco et al. 2007, Seely et al. 2010), including tropical and subtropical plantations (Bi et al. 2007, Blanco and González 2010 a, b). FORECAST offers a detailed simulation of the vegetation and soil processes involved in tree growth and $\mathrm{N}$ cycles, and given its relatively low data requirements to simulate the biogeochemical processes in the soil, it can be used at operational scale with some modifications to explore interactions between forest management, atmospheric deposition and soil acidification. The model has been specifically designed to examine the impacts of different management strategies or ecological disturbance regimes on long-term forest productivity and carbon sequestration through a nutrient balance approach, and it simulates both vegetation and soil processes. Using this model, we explored the 
sensitivity of Chinese fir plantations to long-term chronic $\mathrm{N}$ deposition and soil acidification, and their effects on tree biomass production.

\section{Material and Methods}

\subsection{Chinese fir forest areas in southeast China}

Chinese fir is a subtropical species, natural from the humid mixed subtropical evergreen forests in SE China. Chinese fir is one of the most important timber tree species in China, accounting for $60-80 \%$ of the total area of timber plantations in SE China and one-third at national level, with a total planted surface exceeding 9.21 million hectares (Tian et al. 2011), and a production of 11.4 million $\mathrm{m}^{3} \mathrm{yr}^{-1}$ or $20-25 \%$ of the national commercial timber output (Lu et al. 2002). Its central distribution area is located in Zhejiang, Jiangxi, Hunan and Fujian provinces, where the climate is subtropical humid monsoon, with annual temperatures averaging between 15 to $23^{\circ} \mathrm{C}$ and annual precipitation of $1,100-2,000 \mathrm{~mm}$, increasing from NW to SE. However, Chinese fir can be found in 14 provinces of China, in the region of approximately 22 to $34^{\circ} \mathrm{N}$ and 102 to $123^{\circ} \mathrm{E}$ (Wei et al. 2012). Soils are usually red soils (lateritic clay-dominated Ferrisoils), but they can have very different parent materials. Chinese fir is moderately nutrient demanding and it absorbs soil N preferentially as nitrates (Zhong and Hsuing 1993). In this warm and humid sub-tropical monsoon climate, $\mathrm{N}$ is usually the growth limiting factor. Chinese fir growth responds to $\mathrm{N}$ fertilization in mid and late rotation ( $\mathrm{Li}$ et al. 1993). Chinese fir is moderately sensitive to acid rain, with its volume being reduced by 25 to $56 \%$ when rain $\mathrm{pH}$ is lower than 4.5 (Feng et al. 2002).

The documented history of Chinese fir cultivation can be traced back more than 1,000 years (Wu 1984). Traditionally, Chinese fir plantations were established after native evergreen broad-leaved forests were harvested and slash-burned, commonly planted on slopes of more than $20 \%$, gentler lower slopes generally being used for agriculture. Slopes were sometimes terraced and intercropped with food plants before canopy closure. However, since the 1950s, the plantation area of Chinese fir has been enlarged, and this species has been repeatedly planted on the same sites without intercropping or periods of fallow. In 
modern plantations, site preparation includes slash-burning and tillage to a depth of $20-30 \mathrm{~cm}$, and initial stocking rates of 2500-3600 stems ha ${ }^{-1}$ (Orwa et al. 2009). In some areas litter raking for cattle bed and feedstock is still common, although this practice has been discouraged and is quickly being abandoned. Tending of young seedling stands is carried out 2-3 times during the growing season in each of the first 3 years after planting. Pruning is not usually practiced, as the lower branches eventually self-prune after canopy closure. Two to three thinning are done during the rotation period according to initial density and growth. About 1500 trees $^{-1} \mathrm{a}^{-1}$ are retained as a final crop (Orwa et al. 2009). Chinese-fir is a fast growing species which can reach a level of timber production in monoculture plantations of $450 \mathrm{~m}^{3} \mathrm{ha}^{-1}$ at final harvest age of 25-30 years. Average mean annual increments are 12 to $17 \mathrm{~m}^{3} \mathrm{ha}^{-1}$, at age 20 year, but this species has the potential to reach 20 to $25 \mathrm{~m}^{3} \mathrm{ha}^{-1}$ (Jiang et al. 1982). Farmers have generally used a 25year rotation, with variation from 20 to 30 years depending on site quality (Wu 1984), and presently the tendency is towards 20-year rotations. However, some plantations in Fujian are being harvested as young as 17 years, a trend driven by the increasing demand for timber due to economic development and population increase. At present, most Chinese fir plantations are in the second or third rotation on the same sites; some are thought to be in even later rotations, but this is difficult to confirm due to lack of documentation (Bi et al. 2007).

\subsection{FORECAST model description}

The model FORECAST has been described in detail before (Kimmins et al. 1999, 2010) and therefore only a summary is presented here. FORECAST operates at stand level and annual time steps. The projection of stand growth and ecosystem dynamics is based on a representation of the rates of key ecological processes regulating the availability of, and competition for, light and nutrient resources. The rates of these processes are calculated from a combination of historical bioassay data (biomass accumulation in component pools, stand density, etc.) and measures of certain ecosystem variables (e.g. decomposition rates, photosynthetic saturation curves, etc.) by relating biologically active components (foliage and small roots) with calculations of nutrient uptake, capture of light, and net primary production. 
An exhaustive description of the input data requirements can be found in Kimmins et al. (1999). First, calibration data are assembled that describe the accumulation of biomass (above and below-ground components) in trees and minor vegetation for chronosequences of stands developed on sites that vary in nutritional quality. Tree biomass and stand self-thinning rate data are generated from the height, diameter and stand density from historical growth and yield records in conjunction with species-specific biomass allometric equations. To calibrate the nutritional aspects of the model, data describing the concentration of nutrients in the various biomass components are required. FORECAST also requires data on the degree of shading produced by different quantities of foliage and the response of foliage to different light levels. A comparable but simpler set of data on minor vegetation must also be provided. Also, data describing the rates of decomposition of various litter types and soil organic matter are required for the model to simulate nutrient cycling. Data are obtained from literature, field measurements, or other empirical models ${ }^{1}$. The second stage of calibration requires establishing the initial site conditions by simulating the known or estimated natural disturbance and/or management history of the site. At this stage, the model is run without accounting for nutrient availability to accumulate vegetation, litter and soil organic matter following the historical patterns of accumulation (for a detailed description of this process see Blanco et al. 2007).

The carbon and nitrogen cycles are linked through the use of the foliar nitrogen efficiency (amount of biomass generated in a year per $\mathrm{kg}$ of foliar $\mathrm{N}$ ) as the driving function of the model. Therefore, a limitation in $\mathrm{N}$ uptake will result in a reduction of foliar $\mathrm{N}$, reducing biomass produced by the trees. Nutrient uptake demands on sites of different $\mathrm{N}$ fertility are based on observed biomass accumulation rates and tissue nutrient concentrations on these sites, allowing for internal cycling of nutrients. The calculated uptake demand needed to support the historical growth rates on sites of different productivity permits a definition of nutritional site quality, assuming that moisture is not the major limiting factor in the humid

\footnotetext{
${ }^{1}$ See Supporting Information for a list of sources and values used for parameter calibration (Table S.1).
} 
climate that characterizes the Chinese fir region. Soil fertility in FORECAST (i.e. availability of limiting nutrients, $\mathrm{N}$ in this case) is represented based on empirical input data describing litter and humus decomposition (mass loss) rates, changes in chemistry as decomposition proceeds, and the size of nutrient pools in the mineral soil and humus (cation exchange capacity [CEC] and anion exchange capacity [AEC], respectively). Decomposition rates and ammonium/nitrate ratios in the soil solution are calibrated for each site quality. These parameters implicitly simulate the effects of soil microorganisms on soil organic matter and $\mathrm{N}$ transformations.

Nitrogen cycling in FORECAST is based on a mass balance approach where $\mathrm{N}$ can exist in three distinct pools: 1) the plant biomass pool; 2) the available soil nutrient pool, and 3) the soil organic matter/forest floor pool. Inputs and outputs of $\mathrm{N}$ to the ecosystem are simulated in a four-stage process for each annual time step ${ }^{2}$. The "available N" pool in FORECAST can be assimilated to represent the interchangeable N present in the soil during one year as $\mathrm{NH}_{4}{ }^{+}, \mathrm{NO}_{3}{ }^{-}$or labile organic $\mathrm{N}$ fractions with turnover rates shorter than one year. Effects of atmospheric pollution are simulated using a semi-empirical approach ${ }^{3} \mathrm{~N}$ deposition is simulated as a constant annual $\mathrm{N}$ flux that directly reaches the soil solution and is incorporated into the available $\mathrm{N}$ pool. No mechanistic representation of $\mathrm{H}^{+}$or $\mathrm{S}$ cycles is included in the soil submodel. Rather, the observed empirical effects of different rain $\mathrm{pHs}$ on soil and vegetation are used to modify the related parameters in the model.

\subsection{Simulation of the effects of soil acidification, atmospheric $\mathbf{N}$ deposition and forest management regimes}

A factorial virtual experiment of $4 \mathrm{~N}$ deposition levels combined with 4 rain $\mathrm{pHs}$ was designed to explore the limits of the stand-level ecological responses of Chinese fir plantations. Total (dry + wet) $\mathrm{N}$ deposition rates simulated at each site were $1,7.5,15$ and $30 \mathrm{~kg} \mathrm{~N} \mathrm{ha}^{-1} \mathrm{y}^{-1}$. These levels were based on reported

\footnotetext{
${ }^{2}$ See Figure S.1 in Supporting Information.

${ }^{3}$ See Figure S.2 in Supporting Information.
} 
deposition along southeast China. Pre-industrial pollution levels of $\mathrm{N}$ deposition are considered to be around $1 \mathrm{~kg} \mathrm{~N} \mathrm{ha}^{-1} \mathrm{y}^{-1}$. A level of $\sim 7 \mathrm{~kg} \mathrm{~N} \mathrm{ha}^{-1} \mathrm{y}^{-1}$ is the average deposition in areas with slight industrial development. In heavily industrialized areas, levels ranging from 9 to $50 \mathrm{~kg} \mathrm{~N} \mathrm{ha}^{-1} \mathrm{y}^{-1}$ have been reported, with $30 \mathrm{ha}^{-1} \mathrm{y}^{-1}$ being the most common (Chen and Mulder 2007, Ma et al. 2007). In our scenarios, a level of $1.0 \mathrm{~kg} \mathrm{~N} \mathrm{ha}{ }^{-1} \mathrm{y}^{-1}$ corresponds to non-human influence, $7.5 \mathrm{~kg} \mathrm{~N} \mathrm{ha}^{-1} \mathrm{y}^{-1}$ simulates human settlement but no industrial development, $15 \mathrm{~kg} \mathrm{~N} \mathrm{ha}^{-1} \mathrm{y}^{-1}$ corresponds to light industrialized areas, and $30 \mathrm{~kg} \mathrm{~N} \mathrm{ha}^{-1} \mathrm{y}^{-1}$ represents highly industrialized areas.

The acidification scenarios were defined to mimic the ecophysiological effects at stand level caused by four different rain $\mathrm{pHs}$ as observed in greenhouse experiments. A more detailed description of the experimental design and results and a summary of the main results can be found in $\mathrm{Li} \mathrm{(2010),} \mathrm{Lu}(2010)$ and Liu et al. $(2010 \mathrm{~b})^{4}$. The $\mathrm{pH}$ of 5.6 was considered as the natural rain $\mathrm{pH}$ in this region. The $\mathrm{pH}$ of 4.0 was considered to be representative of the areas with high atmospheric pollution. In addition, the other two extreme $\mathrm{pH}$ values were chosen as a sensitivity test of the limits of these plantations to extreme changes in rain $\mathrm{pH}$. The lowest value $(\mathrm{pH} 2.5)$ is unlikely to be widespread even in a more industrialized future, but it has already been reported in particular cases in the proximity of industrial centers (Chen and Mulder 2007, Ma et al. 2007). The highest value (pH 7.0) it is also uncommon, but it has been reported in areas receiving the deposition of alkaline dust, which in east China could be especially important after sandstorms originated from the Gobi desert area, which are becoming more frequent (Wang et al. 2007).

The empirical studies at ZAFU by Li (2010), Lu (2010) and Liu (2010b) were complemented with descriptions of soil acidification effects on Chinese fir by Shan and Feng (1988), Liao et al. (2000) and Yuan et al. (2007). All these authors reported changes in the four parameters calibrated in FORECAST to simulate soil acidification: CEC, root biomass, litter decomposition rates and ratio $\mathrm{NH}_{4}{ }^{+} / \mathrm{NO}_{3}{ }^{-}$in the soil

\footnotetext{
${ }^{4}$ A detailed description of the greenhouse experiments at ZAFU can be found in the Supporting Information.
} 
solution ${ }^{5}$. Changes in these variables were caused by mobilization of $\mathrm{Al}^{3+}$, and increased presence of $\mathrm{H}^{+}$ and other cations. We did not simulate direct damage of acid rain on leaves and stems as no foliar leaching or other physiological damage was detected at the greenhouse experiments even for the lowest $\mathrm{pH}$. Therefore, our simulation of soil acidification is empirical, whereas the simulation of $\mathrm{N}$ deposition is mechanistic. The use of this approach allows to simulate the observed effects at the same time that the complexity and uncertainty related to unknown parameters remain low (Kimmins et al. 2008). We consider that this assumption is valid to simulate the conditions in our sites as the changes in the soil variables observed in the greenhouse studies integrate the soil chemical processes linked to soil acidification. However, we acknowledge that this methodology prevents FORECAST from being used for similar studies in forest ecosystems for which preliminary field studies are not available.

Simulations were carried out for a poor site (dominant tree height or site index $18 \mathrm{~m}$ at year 50) and a medium-rich site (site index $24 \mathrm{~m}$ at year 50). Initial conditions for each site are presented in Table 1. Forest management was simulated following the standard practices in the area: 2-year old seedlings planted with a stand density of 3,000 stems ha ${ }^{-1}$, and stem-only harvest at year 20. Model performance for the good site was evaluated against independent field data described by Tian (2003) and Rong et al. (2008) for plantations in Fujian and Guangxi provinces with the same site index (26 m at year 25). No validation was possible for the poor site as no reliable records could be found for this type of sites. Several indexes of goodness-of-fit were used: average bias, mean absolute error, determination coefficient $r^{2}$, Reynolds' critical error, Theil's inequality coefficient and modeling efficiency (Blanco et al. 2007). The performance of FORECAST when simulating $\mathrm{N}$ fluxes such as deposition and fertilization and their effects in the forest ecosystem has been successfully tested before (see Blanco et al. 2007) and therefore it was not re-evaluated here.

\section{Results}

${ }^{5}$ See Supporting Information Table S.2. 
FORECAST performed acceptably well, with high model efficiency and $r^{2}$ values indicating a high level of agreement between observed and predicted values (Table 2). However, model predictions were better for the first half of the rotation (until year 25), and there was a slight tendency thereafter to underestimate aboveground biomass and forest litter mass (Figure 1), generating a small negative average bias (Table 2). As the factorial experiment was carried out simulating 20-year rotations, this issue did not influence the results. The model was also able to simulate long-term changes in soil variables such as soil organic matter content or $\mathrm{C}: \mathrm{N}$ ratio following several rotations (Figure 1).

Accumulated harvested biomass after three rotations (60 years) was influenced by the interaction of site quality, $\mathrm{N}$ deposition rate and rain $\mathrm{pH}$. At the poor site, very acidic rain ( $\mathrm{pH} 2.5)$ reduced harvested biomass by up to 48 or $40 \%$ in moderate $\mathrm{N}$ deposition scenarios ( 1 or $7.5 \mathrm{~kg} \mathrm{~N}^{-1}$ year $\left.^{-1}\right)$. However, under higher $\mathrm{N}$ deposition rates (15 or $30 \mathrm{~kg} \mathrm{~N} \mathrm{ha}^{-1} \mathrm{y}^{-1}$ ) harvested biomass was reduced by 19\% (Figure 2). Biomass reductions at the rich site were smaller. The maximum values of accumulated biomass productivity (419 $\mathrm{Mg} \mathrm{ha}^{-1}$ ) were achieved at the poor site only when rain $\mathrm{pH}$ was above 4.5 and $\mathrm{N}$ deposition rate was $15 \mathrm{~kg} \mathrm{~N} \mathrm{ha}^{-1} \mathrm{y}^{-1}$ or higher (Figure 2). Below those bounds, stand productivity was greatly reduced. On the other hand, at the rich site there was a steady increase in accumulated harvested biomass with increasing rain $\mathrm{pH}$ and $\mathrm{N}$ deposition rates, reaching $583 \mathrm{Mg} \mathrm{ha}^{-1}$ after three rotations. However, to obtain the same productivity with rain $\mathrm{pH}$ lower than 5.0, $\mathrm{N}$ deposition had to be higher than $15 \mathrm{~kg} \mathrm{~N} \mathrm{ha}^{-1} \mathrm{y}^{-1}$ (Figure 3). The maximum amounts of nutrients removed in 60 years with the accumulated harvested biomass were $232 \mathrm{~kg} \mathrm{~N} \mathrm{ha}^{-1}, 465 \mathrm{~kg} \mathrm{Ca} \mathrm{ha}^{-1}, 241 \mathrm{~kg} \mathrm{~K} \mathrm{ha}^{-1}, 67 \mathrm{~kg} \mathrm{Mg} \mathrm{ha}^{-1}$ and $213 \mathrm{Mg} \mathrm{Cha}^{-1}$ at the poor site, and $354 \mathrm{~kg} \mathrm{~N} \mathrm{ha}^{-1}, 646 \mathrm{~kg} \mathrm{Ca} \mathrm{ha}^{-1}, 335 \mathrm{~kg} \mathrm{~K} \mathrm{ha}^{-1}, 93 \mathrm{~kg} \mathrm{Mg} \mathrm{ha}^{-1}$ and $295 \mathrm{Mg} \mathrm{C}^{-1}$ at the rich site ${ }^{6}$.

Acid rain made little difference in harvestable volume at the poor site and its effect was smaller than $\mathrm{N}$ deposition. Changes in $\mathrm{N}$ deposition could bring site productivity from close to zero volume produced in

\footnotetext{
${ }^{6}$ See Supplementary info for calibration sources on nutrient concentrations.
} 
60 years up to $400 \mathrm{~m}^{3} \mathrm{ha}^{-1}$ when deposited $\mathrm{N}$ was $25 \mathrm{~kg} \mathrm{ha}^{-1} \mathrm{y}^{-1}$ or more. On the contrary, at the rich site, a combination of both high deposition rates and high rain $\mathrm{pH}$ was needed to produce the maximum accumulated harvestable volume after three rotations (Figure 2).

Soil organic matter accumulated faster under acid rain (Table 3, Figure 4). The combined reductions of $\mathrm{C}$ in aboveground biomass and in SOM were also translated into a reduction in total ecosystem C (Figure 5). The effect of soil acidification depended on the rate of $\mathrm{N}$ deposition, but it reduced ecosystem $\mathrm{C}$ up to by $25 \%$ at the poor site and $19 \%$ at the rich site (Table 3). Soil acidification also influenced the amount of $\mathrm{N}$ being leached out of the Chinese fir plantations at the poor site, with the lowest losses predicted at $\mathrm{pH} 4.5$ and low $\mathrm{N}$ deposition rates (Figure 6). However, the effect size of rain $\mathrm{pH}$ on the magnitude of $\mathrm{N}$ leaching losses was smaller than the effect size of $\mathrm{N}$ deposition rates (Figure 6). Accumulated $\mathrm{N}$ leaching losses were much more sensitive to increases in $\mathrm{N}$ deposition than to decreases in rain $\mathrm{pH}$ at both sites. The maximum values were obtained for the combination of the highest $\mathrm{N}$ deposition rates and rain $\mathrm{pH}$ (Figure 2). Leaching losses concentrated at the beginning and end of each rotation, and increased through time (Figure 6).

\section{Discussion}

\subsection{Effects of atmospheric pollution on biomass production}

Our results indicated that the $\mathrm{N}$ fertilization effect is the major driver for forest growth at these plantations, and the soil acidification effect is comparatively rather small. However, the generalization of this statement for other forest ecosystems should be avoided, given the shortcomings of our empirical approach to model acid rain effects (see section 4.2). Rain $\mathrm{pH}$ values lower than 4.0 are unusual in most of southeast China (Du et al. 2008, Fan and Hong 2001), and they have been reported only in the vicinity of main polluting sources (Fan and Wang 2000). As direct physical damage by acid rain on plant tissues has not been observed at pH values higher than 3.5 (Kennedy 1992, Liu et al. 2010b), the expected influence of acid pollution in this region will be produced by indirect effects on ecosystem productivity as the ones 
simulated here. However, acid pollution could produce significant changes at stand level even at $\mathrm{pHs}$ above the levels of visible leaf damage, accounting for significant reductions of harvested biomass and timber volume, and depletions of ecosystem C capital.

Ecosystem productivity could be affected by reductions in the availability of $\mathrm{N}$, the limiting nutrient in these forests (Li et al. 1993, Liao et al. 2000). Acid rain can inhibit microbial and microfaunal decomposer communities, and as a consequence litter consumption is reduced, leading to litter accumulation (Kennedy 1992). The reduction in litter consumption results in less $\mathrm{N}$ being mineralized and released to the soil solution (Blanco et al. 2011) and therefore $\mathrm{N}$ availability for Chinese fir is reduced. In addition, Chinese fir litter has low quality (i.e. high $\mathrm{C} / \mathrm{N}$ ratio; $\mathrm{Bi}$ et al. 2007), and with the increase in $\mathrm{C}$ sequestered more $\mathrm{N}$ will be immobilized in the litter layer. Ouyang et al. (2008) also described maximum soil $\mathrm{C}$ with pH 4.0 in south China. These authors pointed out that acid rain could influence mineralization of organic $\mathrm{C}$ in acid soils by changing factors such as soil organic $\mathrm{C}$, and $\mathrm{N}$ status. Furthermore, if the relative abundance of $\mathrm{NH}_{4}{ }^{+}$in the soil solution keeps increasing due to atmospheric pollution (Yuan et al. 2007), there could be a reduction in the relative abundance of nitrate in the soil solution, the $\mathrm{N}$ form preferred taken up by Chinese fir. Moreover, soil acidification decreases CEC and base saturation. All these phenomena combined reduce the amount of available $\mathrm{N}$ that can be stored in the soil pool, therefore reducing $\mathrm{N}$ availability for tree uptake and increasing $\mathrm{N}$ limitation. Soil acidification also causes fine root mortality (5 to $10 \%$ biomass reduction; $\mathrm{Li} 2010, \mathrm{Lu} 2010$, Liu et al 2010b). This reduction results in less soil being explored and colonized and therefore less soil $\mathrm{N}$ used for tree uptake.

Our results support the hypothesis that in Chinese fir plantations some of the negative consequences of soil acidification on nutrient availability and limitation to tree growth could be balanced out by $\mathrm{N}$ deposition. Rates of $30 \mathrm{~kg} \mathrm{~N} \mathrm{ha}^{-1} \mathrm{y}^{-1}$ reduced most of the simulated negative effects on nutrient availability caused by acid rain. This $\mathrm{N}$ pollution can actually work as fertilization, increasing tree growth for several years, although this effect may disappear in the long term (Bäck et al. 1995). Forests in SE China are 
developed on old nutrient-poor acid soils (Fan and Hong 2001). Although Chinese fir is adapted to these poor soils, it can take advantage when this limitation is eased by $\mathrm{N}$ deposition, even if soil acidification reduces CEC. This phenomenon can have dramatic effects in the poor sites, which could double their timber production, increasing the amount of $\mathrm{C}$ that could be sequestered by these forests (Wei et al. 2012). Similar counterbalancing of acid effects by $\mathrm{N}$ deposition has been reported before in northern Europe (Nellemann and Thomsen 2001). However, chronic $\mathrm{N}$ input could also reduce the role of $\mathrm{N}$ as a tree growth limiting factor and therefore making other nutrients such as $\mathrm{P}$ to become limiting (Blanco et al. 2005, Braun et al. 2010), and cause nutrient imbalances, and chemical and microbial changes in the soil that could lead to dieback. This phenomenon has not been reported for Chinese fir yet, but it may deserve additional consideration in future research as it could educe growth response to $\mathrm{N}$ deposition. Moreover, $\mathrm{N}$ deposition is intrinsically linked to acid rain and therefore the most realistic scenarios under increased atmospheric pollution are the ones that combine high $\mathrm{N}$ deposition rates with low rain $\mathrm{pHs}$.

On the other hand, high $\mathrm{N}$ deposition rates could have a clear negative environmental effect: important increases in $\mathrm{N}$ leaching out from the forest soil. $\mathrm{N}$ leaching losses are expected only at the first few years of each rotation for pre-industrial $\mathrm{N}$ deposition rates. These loses are generated when the slash produced during conversion of natural mixewoods into plantations decomposes. However, if annual $\mathrm{N}$ deposition rates are higher than $7.5 \mathrm{~kg} \mathrm{ha}^{-1}$, leaching losses quickly increase and is observed along the whole rotation. This could have consequences for stream water quality, eutrophication, changes in biodiversity of river and lakes, and reduction of suitable sources of drinking water for human and animal consumption. This phenomenon has been reported before in other regions (Smith 1990), and it is a consequence of forests reaching the $\mathrm{N}$ saturation state (Aber et al. 1998). Although acid rain could increase $\mathrm{N}$ sequestration in the SOM, this effect could be not enough to significantly reduce N leaching. Similarly, it has been hypothesized that high litter $\mathrm{C} / \mathrm{N}$ ratios, such in Chinese fir litter, could prevent $\mathrm{N}$ leaching (Yoh 2001), but it seems that this is only true in Chinese fir plantations for moderate or low $\mathrm{N}$ deposition rates. 
Our results indicate that a deposition rate of $30 \mathrm{~kg} \mathrm{~N} \mathrm{ha}^{-1} \mathrm{y}^{-1}$ could produce a saturation of the forest ( $\mathrm{N}$ leached exceeding $\mathrm{N}$ inputs) relatively fast, after just one rotation (20 years). This is a level of $\mathrm{N}$ deposition similar to the ones reported as causing other forest soils to become $\mathrm{N}$-saturated (Braun et al. 2010). Considering that in some areas of southeast China these deposition rates have been recorded since the beginning of China's industrialization in the early 1980s, it is likely that effects on $\mathrm{N}$ saturation in Chinese fir forests could be apparent in the near future, even though intensive forest management practices in Chinese fir plantations have usually lead to reductions in ecosystem $\mathrm{N}$ capital (Bi et al. 2007). However, in poor sites, lower deposition rates of $15 \mathrm{~kg} \mathrm{~N} \mathrm{ha}^{-1} \mathrm{y}^{-1}$ but sustained for several decades could also producer $\mathrm{N}$ saturation of the ecosystem, as the plateau on biomass productivity in Figure 2 shows. Soils in the coastal provinces of Zhejiang, Fujian, Guangdong and Guangxi could reach the N saturation conditions faster than in other regions of the world, as they have been identified as especially sensitive due to their small buffering capacity and slow mineral weathering rates (Smith 1990, Tao and Feng 2000). Our simulations show that under the high levels of $\mathrm{N}$ deposition already reported in SE China, some Chinese fir plantations could leach out important amounts of $\mathrm{N}$ in just one or two rotations (20 to 40 years). This is in agreement with the first reports of N-saturated forests in China (Fang et al. 2009).

\subsection{Simulation limitations}

The good agreement between observed and simulated variables provided by the evaluation tests gives confidence on our results. Our projections of leaching losses during the stand growing stage are also similar to reports from Chinese forests (Fang et al. 2011) and the peaks following harvesting are in the same range as values reported for other tropical plantations (Mackensen et al. 2003). However, as in any modeling exercise, there are some limitations. Long-term data on the effects of acid rain and $\mathrm{N}$ deposition in China are scarce (An et al. 2001) and we have not found any report on its effects on foliar $\mathrm{N}$ for Chinese fir. Therefore, we have kept foliar $\mathrm{N}$ concentrations unaffected by changes in atmospheric pollution. Empirical research supports this approach (Aber et al. 1989, Liu et al. 2010b). However, reports for other species have shown a positive correlation between $\mathrm{N}$ deposition rates and foliar $\mathrm{N}$ (Flückiger and 
Braun 1998). If the same effect would be true for Chinese fir, this effect could produce a reduction in $\mathrm{N}$ leached as more $\mathrm{N}$ would be retained in the foliar biomass, although the significance of this reduction would depend on the change in foliar N concentration. Similarly, no acid rain effects on diseases or pests have been included due to lack of observations of these phenomena in Chinese fir plantations. However, an increase in disease and insect attacks caused by atmospheric pollution has been suggested for other species (Flückiger and Braun 1998). If similar events happened in Chinese fir plantations, tree growth would be lower than predicted and therefore part of the fertilization effect of $\mathrm{N}$ deposition would be lost, increasing the negative effects of soil acidification. Finally, our assumption of no direct physiological damage of acid rain on trees for the lowest $\mathrm{pH}$, based on the empirical observations by $\mathrm{Li}$ (2010) and Liu (2010), remains to be tested in field conditions from which no reports have been found. If physiological damage is in fact produced, tree growth would be lower than estimated here. However, this condition would affect only the few remaining forests close to the large industrial and urban centers where exceptionally low rain pH has been reported (Chen and Mulder 2007, Ma et al. 2007).

Under continuous acid rain a reduction in soil $\mathrm{pH}$ would be expected, producing a mobilization of $\mathrm{Al}^{3+}$ that would displace other base cations from the soil solution, and therefore increasing their leaching losses and reducing CEC (Smith 1990). At the same time, this could increase the leaching of base cations, which if significant could produce in the long term limitation of other nutrients rather than N. Due to its toxicity, $\mathrm{Al}^{3+}$ can also reduce decomposition and affect root growth, increasing nutrient limitation for trees (Mulder et al. 2001). As indicated above, we have not directly simulated these effects because no reports have mentioned them in Chinese fir plantations yet. In absence of accurate parameters it is preferable to keep model complexity low to reduce uncertainty (Kimmins et al. 2008). However, our parameterization of soil variables was based on empirical observations that intrinsically included these phenomena. In addition, biomass removal has been identified as a cause for soil acidification due to the permanent removal of base cations (Thiffault et al. 2011). However, this issue is likely limited in our conditions, as we have simulated stem-only harvesting, which extracts a maximum of 772 and $1074 \mathrm{~kg} \mathrm{ha}^{-1}$ base cations after 60 years of 
management. These amounts are compensated by the atmospheric Ca deposition, which in this region could reach values of 960 to $1920 \mathrm{~kg} \mathrm{ha}^{-1}$ in the same 60-year period (Larssen et al. 2011). Finally, soil acidification generally reduces nitrification and denitrification and therefore reduces nitrate leaching and gaseous $\mathrm{N}_{2}$ emissions. As denitrification is not explicitly simulated in FORECAST but assumed to be included in the estimated leaching losses, this effect could produce leaching losses lower than simulated (Kimmins et al. 1999). However, as the more severe soil acidification would be joined to the higher $\mathrm{N}$ deposition rates, this issue would likely be minor.

\subsection{Conclusions}

Chronic anthropogenic $\mathrm{N}$ deposition could provide the nutrients needed by Chinese fir plantations to offset the losses of $\mathrm{N}$ availability caused by soil acidification, and even produce a fertilizing effect that could increase ecosystem productivity. On the other hand, very acidic precipitation combined with low $\mathrm{N}$ deposition (a potential future scenario in which $\mathrm{N}$ pollution is reduced but sulfuric pollution is increased) could produce important reductions on ecosystem productivity and $\mathrm{C}$ capital. Other negative effects of atmospheric pollution would be high $\mathrm{N}$ leaching losses. It is important to mention that this paper discusses only the effects on biomass production. As there are other ecosystems that could be more sensitive to $\mathrm{N}$ than these plantations, we warn against an extrapolation of our results to other forest types. In addition, our virtual experiment demonstrates that linking modeling studies of forest management with estimations of air pollution effects can provide valuable information to design better strategies to adapt forest management to the challenges of rapid industrialization in this area. All things considered, there is also a strong need to set up networks of research sites in this region to fill the knowledge gap related to longterm effects of atmospheric pollution in Chinese forests.

\section{Acknowledgements}

Thanks are due to Dr. Jun Bi for creating the first version of the calibration data set, and to Dr. Brad Seely and Dr. Hamish Kimmins for their feedback on simulating the acid rain scenarios. Guang Qin helped to 
run the simulations. This project was funded by the British Columbia - China Innovation and Commercialization Strategic Development Program (British Columbia Innovation Council - Project \# ICSD-2007-Wei-Kimmins, British Columbia Innovation Council - BCIC).

\section{References}

3 Aber, J.D., Nadelhoffer, K.J., Steudler, P., and Melillo, J. 1989. Nitrogen Saturation in Northern Forest 4 Ecosystems. BioScience 39(6): 378-386.

5 Aber, J., McDowell, W., NAdelhoffer, K., Magill, A., Berntson, G., Kamakea, M., McNulty, S., Currie, 6 W., Rustad, L., and Fernández, I. 1998. Nitrogen saturation in temperate forest ecosystems. BioScience $7 \quad$ 48(11): 921-934.

8 An, J., Zhou, L., Huang, M., Li, H., Otoshi, T., and Matsuda, K. 2001. A literature review of uncertainties

9 in studies of critical loads for acidic deposition. Water Air Soil Poll. 130(1-4): 1205-1210. DOI:

$10 \quad$ 10.1023/A:1013965616174.

11 Bäck, J., Huttunen, S., Turunen, M., and Lamppu, J. 1995. Effects of acid rain on growth and nutrient 12 concentrations in Scots pine and Norway spruce seedlings grown in a nutrient-rich soil. Environ Pollut.

13 89(2): 177-187. DOI:10.1016/0269-7491(94)00054-H

14 Bélanger, N., Courchesne, F., Côté, B., Fyles, J.W., Warfvinge, P., and Hendershot, W.H. 2002.

15 Simulation of soil chemistry and nutrient availability in a forested ecosystem of southern Quebec. Part II.

16 Application of the SAFE model. Environ. Modell. Softw. 17(5): 447-465. doi:10.1016/S1364-

$17 \quad 8152(02) 00007-5$.

18 Bi, J., Blanco, J.A., Kimmins, J.P., Ding, Y., Seely, B., and Welham, C. 2007. Yield decline in Chinese

19 Fir plantations: A simulation investigation with implications for model complexity. Can. J. For. Res.

20 37(9): 1615-1630. DOI: 10.1139/X07-018.

21 Blanco, J.A., Imbert, J.B., and Castillo F.J. 2011. Thinning affects Pinus sylvestris needle decomposition 22 rates and chemistry differently depending on site conditions. Biogeochem. 106: 397-414. DOI:

$23 \quad 10.1007 / \mathrm{s} 10533-010-9518-2$. 
24 Blanco, J.A., and González, E. 2010a. Exploring the sustainability of current management prescriptions

25 for Pinus caribaea plantations in Cuba: a modelling approach. J. Trop. For. Sci. 22(2): 139-154.

26 Blanco, J.A., and González, E. 2010b. The legacy of forest management in tropical forests: analysis of its

27 long-term influence with ecosystem-level model. Forest Systems 19(2): 249-262.

28 Blanco, J.A., Seely, B., Welham, C., Kimmins, J.P., and Seebacher, T.M. 2007. Testing the performance

29 of FORECAST, a forest ecosystem model, against 29 years of field data in a Pseudotsuga menziesii

30 plantation. Can. J. For. Res. 37: 1808-1820. DOI: 10.1139/X07-041.

31 Blanco, J.A., Zavala, M.A., Imbert, J.B., and Castillo F.J. 2005. Sustainability of forest management

32 practices: Evaluation through a simulation model of nutrient cycling. For. Ecol. Manage. 213(1-3): 209-

33 228. doi:10.1016/j.foreco.2005.03.042.

34 Bonten, L.T.C., Mol-Djikstra, J.,Wieggers, H.J.J., de Vries, W., van Pul, W.A.J., and Van der Hoek, K.W.

35 2009. Linking nitrogen deposition to nitrate concentrations in groundwater below nature areas:

36 Modelling approach and data requirements. Wageningen, Alterra, Alterra-rapport 1881.

37 Braun, S., Thomas, V.F.D., Quiring, R., and Flückiger, W. 2010. Does nitrogen deposition increase forest

38 production? The role of phosphorus. Environ. Pollut. 148(6): 2043-2052.

39 doi:10.1016/j.envpol.2009.11.030.

40 Chen, X.Y., and Mulder, J. 2007. Indicators for nitrogen status and leaching in subtropical forest

41 ecosystems, South China. Biogeochem. 82(2): 165-180. DOI: 10.1007/s10533-006-9061-3.

42 Cheng J., Wang S. 2007. Dynamic of soil carbon pool in Cunninghamia lanceolata plantation: recent

43 advances and future prospects. Guangxi Forestry Science 36 (3):147-163.

44 Du, C.Y., Zeng, G.M., Zhang, G., Tang, L., Li, X.D., Huang, D.L., Huang, L., and Jiang, Y.M. 2008.

45 Input-output budgets for inorganic nitrogen under acid rain in a subtropical evergreen mixed forest in

46 central-south China. Water Air Soil Poll. 190(1-4): 171-181. DOI: 10.1007/s11270-007-9590-y.

47 Emmett, B.A., Boxman, D., Bredemeier, M., Gundersen, P., Kjønaas, O.J., Moldan, F., Schleppi, Tietema, 48 A., and Wright, R.F. 1998. Predicting the effects of nitrogen deposition in conifer stands: evidence from 49 the NITREX ecosystem-scale experiments. Ecosystems 1(4): 352-360. DOI: 10.1007/s100219900029. 
50 Fan, H.B., and Hong, W. 2001. Estimation of dry deposition and canopy exchange in Chinese fir

51 plantations. For. Ecol. Manage. 147(2-3): 88-107. doi:10.1016/S0378-1127(00)00469-2.

52 Fan, H.B., and Wang, Y.H. 2000. Effects of simulated acid rain on germination, foliar damage,

53 chlorophyll contents and seedling growth of five hardwood species growing in China. For. Ecol.

54 Manage. 126(3): 321-329. doi:10.1016/S0378-1127(99)00103-6.

55 Fang, Y., Zhu, W., Gundersem, P., Mo, J., Zhou, G., and Yoh, M. 2009. Large loss of dissolved organic

56 nitrogen from nitrogen-saturated forests in subtropical China. Ecosystems 12(1): 33-45. DOI:

$57 \quad 10.1007 / \mathrm{s} 10021-008-9203-7$

58 Fang, Y., Gundersen, P., Vogt, R.D., Koba, K., Cheng, F., Chen, X.Y., and Yoh, M. 2011. Atmospheric

59 deposition and leaching of nitrogen in Chinese forest ecosystems. J. For. Res. 16: 341-350. DOI:

$60 \quad 10.1007 / \mathrm{s} 10310-011-0267-4$

61 Feng, Z.W., Miao, H., Zhang, F.Z., and Huang, Y.Z., 2002. Effects of acid deposition on terrestrial

62 ecosystems and their rehabilitation strategies in China. J. Environ. Sci. 14: 227-233.

63 Fujimaki, R., Sakai, A., and Kaneko, N. 2009. Ecological risks in anthropogenic disturbance of nitrogen

64 cycles in natural terrestrial ecosystems. Ecol. Res. 24(5): 955-964. DOI: 10.1007/s11284-008-0578-x.

65 Flückiger, W., and Braun, S. 1998. Nitrogen deposition in Swiss forests and its possible relevance for leaf

66 nutrient status, parasite attacks and soil acidification. Environ. Poll. 102(1-S1): 69-76.

67 doi:10.1016/S0269-7491(98)80017-1.

68 Hartman, M.D., Baron, J.S., and Ojima, D.S., 2007. Application of a coupled ecosystem-chemical

69 equilibrium model, DayCent-Chem, to stream and soil chemistry in a Rocky Mountain watershed. Ecol.

70 Modell. 200(3-4): 493-510. doi:10.1016/j.ecolmodel.2006.09.001.

71 Ito, K., 2007. Application of the simplified biogeochemical process (SIMPLB) model to determine the

72 impact of acidic deposition on a Japanese cedar forest soil. Ecol. Model. 205(1-2): 265-269.

73 doi:10.1016/j.ecolmodel.2007.02.017.

74 Jiang, Z.L., Ye, J.Z., and Zhou, B.L. 1982. Tending Felling of Chinese Fir Plantations (in Chinese). China 75 Forestry Press House. Beijing. 
76 Kennedy, I.R., 1992. Acid rain and acid soil. Research Studies Press/Wiley, Chichester. UK.

77 Kimmins, J.P., Mailly, D. and Seely, B. 1999. Modelling forest ecosystem net primary production: the

78 hybrid simulation approach used in FORECAST. Ecol. Model. 122(3): 195-224. doi:10.1016/S0304-

$79 \quad 3800(99) 00138-6$.

80 Kimmins, J.P., Blanco, J.A., Seely, B., Welham, C., and Scoullar, K. 2008. Complexity in modelling

81 forest ecosystems: how much is enough? For. Ecol. Manage. 256(10): 1646-1658.

82 doi:10.1016/j.foreco.2008.03.011.

83 Kimmins, J.P., Blanco, J.A., Seely, B., Welham, C., Scoullar, K. 2010. Forecasting Forest Futures: A

84 Hybrid Modelling Approach to the Assessment of Sustainability of Forest Ecosystems and their Values.

85 Earthscan, London, UK.

86 Larssen, T., Lydersen, E., Tang, D., He, Y., Gao, J., Liu, H., Duan, L., Seip, H.M., Vogt, R.D., Mulder, J.,

87 shao, M., Wang, Y., Shang, H., Zhang, X., Solberg, S., Aas, W., Økland, T., Eilertsen, O., Angell, V.,

88 Liu, Q., Zhao, D., Xiang, R., Xiao, J., and Luo, J. 2006. Acid rain in China. Environ. Sci. Technol. 40(2):

89 418-425. DOI: 10.1021/es0626133.

90 Larssen, T., Duan, L., and Mulder, J. 2011. Deposition and leaching of sulfur, nitrogen and calcium in

91 four forested catchments in China: implications for acidification. Environ. Sci. Technol. 451 192-1198.

92 DOI: dx.doi.org/10.1021/es103426p.

93 Li, J. 2010. The Effects of Simulated Acid Rain on Photosynthetic Eco-physiology of Four Common

94 Broad-leaved and Conifers Seedlings in Zhejiang. MSc thesis. Zhejiang Agriculture and Forestry

95 University, Hangzhou. PR China.

96 Li, Y.Q., Ji, J.S., and Chen D.D. 1993. Growth responses of middle-aged Chinese fir plantation to

97 fertilizer application. For. Res. 6(1-3): 390-396.

98 Liao, L.P., Gao, H., Wang, S.L., Ma, Y.Q., Huang, Z.Q., and Yu, X.J., 2000. The effects of nitrogen

99 addition on soil nutrient leaching and the decomposition of Chinese fir leaf litter. Acta Phytoecologica

$100 \quad$ Sinica 24(1): 34-39.

101 Liu, X., Duan, L., Mo, J., Du, E., Shen, J., Lu, X., Zhang, Y., Zhou, X., He, C., and Zhang, F. 2010a. 
102 Nitrogen deposition and its ecological impact in China: an overview. Enviton. Poll. 159(10):2251-2264.

103 doi:10.1016/j.envpol.2010.08.002.

104 Liu, Y., Jiang, H., Li, Yahong, and Yuan, H. 2010b. A short-term effect of simulated acid rain on the soil

105 respiration of the system of Chinese fir seedling-soil. Acta Ecologica Sinnica 30(8): 2010-2017.

106 Lu, M. 2010. Effect of simulated acid rain on growth and physiological photosynthesis of seedlings of

107 three important tree species in Zhejiang province. MSc thesis. Zhejian Agriculture and Forestry

108 University, Hangzhou. PR China.

109 Lu, Z.H., Wu, G., Ma, X., Bai, G.X. 2002. Current situation of Chinese forestry tactics and strategy of

110 sustainable development. J. Forestry Res. 13:319-22.

111 Ma, X., Heal, K.V., Liu, A., and Jarvis, P.G. 2007. Nutrient cycling and distribution in different-aged

112 plantations of Chinese fir in southern China. For. Ecol. Manage. 243(1): 61-74.

113 doi:10.1016/j.foreco.2007.02.018.

114 Mackensen, J., Klinge, R., Ruhiyat, D., and Fölster H. 2003. Assessment of management-dependent

115 nutrient losses in tropical industrial tree plantations. Ambio 32(2): 106-112.

116 Mulder, J., De Witt, H.A., Boonen, H.W.J., and Bakken, L.R. 2001. Increased levels of aluminium in

117 forest soils: effects on the stores of soil organic carbon. Water Air Soil Poll. 130(1): 989-994. DOI:

$118 \quad 10.1023 / \mathrm{A}: 1013987607826$

119 Nellemann, C., and Thomsen, M.G. 2001. Long-term changes in forest growth: potential effects of

120 nitrogen deposition and acidification. Water Air Soil Poll. 128(3-4): 197-205. DOI:

$121 \quad$ 10.1023/A:1010318800180.

122 Ouyang, X.-J., Zhou, G.-Y., Huang, Z.-L., Liu, J.-X., Zhang, D.-Q., and Li, J. 2008. Effect of simulated

123 acid rain on potential carbon and nitrogen mineralization in forest soils. Pedosphere 18(4): 503-514.

124 doi:10.1016/S1002-0160(08)60041-7.

125 Orwa, C., Mutua, A., Kindt, R., Jamnadass, R., and Simons, A. 2009. Agroforestree Database:a tree

126 reference and selection guide version 4.0 . Retrieved from http://www.worldagroforestry.org/af/treedb/

127 Posch M., Reinds G.J. 2009. A very simple dynamic soil acidification model for scenario analysis and 
128 target load calculations. Environ. Modell. Softw. 24(3): 329-340. doi:10.1016/j.envsoft.2008.09.007.

129 Reinds G.J., Posch M., and Leemans R. 2009. Modelling recovery from soil acidification in European

130 forests under climate change. Sci. Total Environ. 407(21): 5663-5673.

131 doi:10.1016/j.scitotenv.2009.07.013.

132 Rong, Y., He, B., Huang, H.C., Huang, H.Z., Fan D.H., Chen, Y.P., and Wei, Z.M. 2008. Biomass

133 productivity of the second generation Cunninghamia lanceolate plantation in northwest of Guangxi.

134 Journal of Guangxi Agricultural and Biological Science 27(4): 451-455.

135 Seely, B., Welham, C., and Blanco, J.A. 2010. Towards the application of soil organic matter as an

136 indicator of ecosystem productivity: Deriving thresholds, developing monitoring systems, and

137 evaluating practices. Ecol. Indic. 10(5): 999-1008. doi:10.1016/j.ecolind.2010.02.008.

138 Shan, Y., and Feng, Z. 1988. Effects of acid rain on younglings of Pinus massoniana and Cunninghamia

139 lanceolata. Acta Scientiae Circumstantiae 3: 307-315.

140 Smith, W.H. 1990. Air pollution and forests: interaction between air contaminants and forest ecosystems,

141 second ed, Springer-Verlag, New York.

142 Solberg, S., Adreassen, K., Clarke, N., Tørseth, K., Tveito, O.E., Strand, G.H., and Tomter, S. 2004. The

143 possible influence of nitrogen and acid deposition on forest growth in Norway. For. Ecol. Manage,

144 192(2-3): 241-249. doi:10.1016/j.foreco.2004.01.036.

145 Streets, D.G., and Waldhoff, S.T., 2000. Present and future emissions of air pollutants in China: $\mathrm{SO}_{2}, \mathrm{NO}_{\mathrm{x}}$,

146 and CO. Atmosphere. Environ. 34(3): 363-374. doi:10.1016/S1352-2310(99)00167-3.

147 Tao, F., and Feng, Z. 2000. Terrestrial ecosystem sensitivity to acid deposition in south China. Water Air

148 Soil Poll. 118(3-4): 231-243. DOI: 10.1023/A:1005139719658

149 Tian, D. L. 2003. Chinese fir forest ecology. Science Press, Beijing. PR China.

150 Tian, D., Xiang, W., Chen, X., Yan, W., Fang, X., Kang, W., Dan, X., Peng, C. and Peng, Y. 2011. A

151 long-term evaluation of biomass production in first and second rotations of Chinese fir plantations at the

152 same site. Forestry 84(4). DOI: 10.1093/forestry/cpr029.

153 Thiffault, E., Hannam, K.D., Paré, D., Titus, B.D., Hazlett, P.W., Maynard, D.G., and Brais, S. 2011. 
154 Effects of forest biomass harvesting on soil productivity in boreal and temperate forests - A review.

155 Environ. Rev. 19: 278-309. DOI: 10.1139/A11-009.

156 Thomas, R.Q., Canham, C.D., Weathers, K.C., and Goodale, C.L., 2010. Increased tree carbon storage in

157 response to nitrogen deposition in the US. Nature Geosci. 3: 13-17. doi:10.1038/ngeo721.

158 Wang, Y., Solberg, S., Yu, P., Myking, T., Vogt, R.D., and Du, S. 2007. Assessments of tree crown

159 condition of two Masson pine forests in the acid rain region in south China. For. Ecol. Manage. 242:

160 530-540. doi:10.1016/j.foreco.2007.01.065.

161 Wei, X., Blanco, J.A., Jiang, H., Kimmins, J.P. 2012. Effects of nitrogen deposition on carbon

162 sequestration in Chinese fir forests. Sci. Tot. Environ. in press.

163 Wu, Z.L., (ed). 1984. Chinese fir (in Chinese). China Forestry Publishing House. Beijing.

164 Yoh, M., 2001. Soil C/N ratio as affected by climate: an ecological factor of forest $\mathrm{NO}_{3}{ }^{-}$leaching. Water

165 Air Soil Poll. 130: 661-666. DOI: 10.1023/A:1013860830153.

166 Yuan, Y.-H., Fan, H.-B., Wang, Q., Qiu, X.-Q., Chen, Q.-F., Li, Y.-Y., Huang, Y.-Z., and Liao, Y.-C.

167 2007. Available nutrients with increased $\mathrm{n}$ deposition in soils of Cunninghamia lanceolata. Journal of

168 Zhejiang Forestry College 24: 437-444.

169 Zhang, X.Q., Kirschbaum, M.K.U., Hou, Z., and Guo, Z. 2004. Carbon stock changes in successive

170 rotations of Chinese-fir (Cunninghamia lanceolata (Lamb.) Hook) plantations. For. Ecol. Manage.

171 202(1-3): 131-147. doi:10.1016/j.foreco.2004.07.032.

172 Zhang, Y., Dore, A.J., Ma, L., Liu, X.J., Ma, W.Q., Cape, J.N., and Zhang, F.S., 2010. High resolution

173 inventory of agricultural ammonia emissions in North China Plain. Env. Pollution 158(2): 490-501.

174 Zhao, D., and Sun, B., 1986. Air Pollution and Acid Rain in China. Ambio 15: 2-5.

175 Zhao, Y., Duan, L., Xing, J., Larssen, T., Nielsen, C., and Hao, J.M., 2009. Soil acidification in China: is

176 controlling $\mathrm{SO}_{2}$ emissions enough? Environ. Sci. Technol. 43(21): 8021-8026. DOI: 10.1021/es901430n.

177 Zhong, A.L., and Hsiung, W.Y., 1993. Evaluation and diagnosis of tree nutritional status in Chinese-fir

178 (Cunninghamia lanceolata (Lamb) Hook) plantations, Jiangxi, China. For. Ecol. Manage. 62: 245-270. 


\section{Tables}

Table 1. Initial conditions for simulations (values at year zero).

\begin{tabular}{lrr}
\hline Variable & Poor site & Rich site \\
\hline Site index (top height in m at year 50) & 18.0 & 26.0 \\
Forest floor mass $\left(\mathrm{Mg} \mathrm{ha}^{-1}\right)$ & 24.05 & 49.31 \\
Humus mass $\left(\mathrm{Mg} \mathrm{ha}^{-1}\right)$ & 59.73 & 73.07 \\
Belowground $\mathrm{C}\left(\mathrm{Mg} \mathrm{ha}^{-1}\right)$ & 37.74 & 122.52 \\
Available soil $\mathrm{N}\left(\mathrm{kg} \mathrm{ha}^{-1}\right)$ & 139.19 & 202.62 \\
\hline
\end{tabular}


Table 2. Indexes of FORECAST performance for simulations of 50-year rotations compared with field data by Tian (2003) and Rong et al. (2008). e*: value of Reynolds' critical error at two different levels of confidence (95\% and $80 \%)$.

\begin{tabular}{lcccc}
\hline \multicolumn{1}{c}{$\begin{array}{c}\text { Measurement of } \\
\text { model performance }\end{array}$} & $\begin{array}{c}\text { Top } \\
\text { height }\end{array}$ & $\begin{array}{c}\text { Dominant } \\
\text { DBH }\end{array}$ & $\begin{array}{c}\text { Aboveground } \\
\text { biomass }\end{array}$ & $\begin{array}{c}\text { Forest floor } \\
\text { litter mass }\end{array}$ \\
\hline Average bias & $0.66 \mathrm{~m}$ & $-0.47 \mathrm{~cm}$ & $-5.89 \mathrm{Mg} \mathrm{ha}^{-1}$ & $0.01 \mathrm{Mg} \mathrm{ha}^{-1}$ \\
Mean absolute deviation & $1.01 \mathrm{~m}$ & $0.98 \mathrm{~cm}$ & $11.38 \mathrm{Mg} \mathrm{ha}^{-1}$ & $0.59 \mathrm{Mg} \mathrm{ha}^{-1}$ \\
$r^{2}$ & 0.97 & 0.96 & 0.95 & 0.82 \\
Theil's inequality coefficient & 0.07 & 0.07 & 0.13 & 0.21 \\
Modelling efficiency & 0.96 & 0.92 & 0.95 & 0.85 \\
$\mathrm{e}^{*}(\alpha=0.05)$ & $1.63 \mathrm{~m}$ & $1.69 \mathrm{~m}$ & $21.91 \mathrm{Mg} \mathrm{ha}^{-1}$ & $1.03 \mathrm{Mg} \mathrm{ha}^{-1}$ \\
$\mathrm{e}^{*}(\alpha=0.20)$ & $1.23 \mathrm{~m}$ & $1.27 \mathrm{~m}$ & $15.94 \mathrm{Mg} \mathrm{ha}^{-1}$ & $0.78 \mathrm{Mg} \mathrm{ha}^{-1}$ \\
\hline
\end{tabular}


Table 3. Values of average ecosystem $\mathrm{C}$ and soil organic matter (SOM) at rotation end for different combinations of rain $\mathrm{pH}$ and $\mathrm{N}$ deposition rates in two sites of different quality (Poor site: top height $18 \mathrm{~m}$ at year 50; Rich site: $24 \mathrm{~m}$ ). Percentages are referred to the value for $\mathrm{pH} 5.6$ for each $\mathrm{N}$ deposition rate.

\begin{tabular}{|c|c|c|c|c|c|c|}
\hline \multirow{2}{*}{ Site Quality } & \multirow{2}{*}{ Rain $\mathrm{pH}$} & \multirow{2}{*}{$\frac{\mathrm{N} \text { deposition rate }}{\mathrm{kg} \mathrm{ha}^{-1} \mathrm{y}^{-1}}$} & \multicolumn{2}{|c|}{ Ecosystem C } & \multicolumn{2}{|c|}{ SOM } \\
\hline & & & $\mathrm{Mg} \mathrm{ha}^{-1}$ & $\%$ & $\mathrm{Mg} \mathrm{ha}^{-1}$ & $\%$ \\
\hline \multirow[t]{16}{*}{ Poor } & 2.5 & 1.0 & 56.2 & 75 & 65.6 & 99 \\
\hline & & 7.5 & 74.9 & 80 & 73.5 & 102 \\
\hline & & 15.0 & 86.5 & 76 & 82.2 & 107 \\
\hline & & 30.0 & 124.1 & 91 & 91.8 & 114 \\
\hline & 4.0 & 1.0 & 68.4 & 91 & 68.5 & 104 \\
\hline & & 7.5 & 88.0 & 94 & 77.1 & 107 \\
\hline & & 15.0 & 106.9 & 94 & 81.5 & 107 \\
\hline & & 30.0 & 136.0 & 100 & 89.6 & 111 \\
\hline & 5.6 & 1.0 & 75.1 & 100 & 66.0 & 100 \\
\hline & & 7.5 & 94.0 & 100 & 72.0 & 100 \\
\hline & & 15.0 & 113.4 & 100 & 76.8 & 100 \\
\hline & & 30.0 & 136.2 & 100 & 80.8 & 100 \\
\hline & 7.0 & 1.0 & 75.1 & 100 & 65.0 & 98 \\
\hline & & 7.5 & 92.9 & 99 & 73.1 & 101 \\
\hline & & 15.0 & 113.0 & 100 & 77.0 & 100 \\
\hline & & 30.0 & 134.4 & 99 & 77.4 & 96 \\
\hline \multirow[t]{16}{*}{ Rich } & 2.5 & 1.0 & 107.1 & 81 & 77.4 & 115 \\
\hline & & 7.5 & 129.1 & 82 & 75.6 & 105 \\
\hline & & 15.0 & 152.4 & 88 & 89.5 & 103 \\
\hline & & 30.0 & 185.0 & 100 & 94.2 & 111 \\
\hline & 4.0 & 1.0 & 118.6 & 90 & 91.0 & 109 \\
\hline & & 7.5 & 143.4 & 91 & 97.7 & 104 \\
\hline & & 15.0 & 168.7 & 97 & 102.9 & 108 \\
\hline & & 30.0 & 188.7 & 102 & 112.9 & 115 \\
\hline & 5.6 & 1.0 & 131.8 & 100 & 86.0 & 100 \\
\hline & & 7.5 & 157.4 & 100 & 96.1 & 100 \\
\hline & & 15.0 & 174.0 & 100 & 108.2 & 100 \\
\hline & & 30.0 & 184.5 & 100 & 117.5 & 100 \\
\hline & 7.0 & 1.0 & 137.2 & 104 & 78.3 & 96 \\
\hline & & 7.5 & 159.3 & 101 & 92.7 & 96 \\
\hline & & 15.0 & 175.2 & 101 & 99.5 & 95 \\
\hline & & 30.0 & 182.5 & 99 & 102.0 & 95 \\
\hline
\end{tabular}




\section{Figure captions}

Figure 1. Panels A to D: Comparison between simulated values of four variables of biomass and litter (top four panels and field values reported by Tian (2003) and Rong et al. (2008) for a Chinese fir plantation with a 50-year rotation in a rich site in SE China with low levels of $\mathrm{N}$ deposition and rainfall $\mathrm{pH}$ of 5.6. Panel E: Observed and predicted organic matter at the end of the $2^{\text {nd }}$ and $3^{\text {rd }} 20$-year rotations, relative to the $1^{\text {st }}$ rotation. Panel F: Observed and predicted C:N ratio at the end of the $2^{\text {nd }}$ and $3^{\text {rd }} 20$-year rotations, relative to the $1^{\text {st }}$ rotation Observed soil data calculated from Zhang et al. (2004) and Cheng and Wang (2007).

Figure 2. Combined effects of acid rain and $\mathrm{N}$ deposition on accumulate harvested aboveground biomass (stem only harvesting; top panel), harvestable volume (stems with diameter at $1.30 \mathrm{~m}$ height $>7.5 \mathrm{~cm}$; medium panel), and $\mathrm{N}$ leaching losses (bottom panel), after 60 years of management of at two sites of different quality.

Figure 3. Evolution of aboveground biomass in Chinese fir plantations established in rich and poor sites with four different $\mathrm{N}$ deposition rates and four levels of rain $\mathrm{pH}$.

Figure 4. Evolution of soil organic matter in Chinese fir plantations established in rich and poor sites with four different $\mathrm{N}$ deposition rates and four levels of rain $\mathrm{pH}$.

Figure 5. Evolution of ecosystem carbon in Chinese fir plantations established in rich and poor sites with four different $\mathrm{N}$ deposition rates and four levels of rain $\mathrm{pH}$.

Figure 6. Evolution of nitrogen leaching losses in Chinese fir plantations established in rich and poor sites with four different $\mathrm{N}$ deposition rates and four levels of rain $\mathrm{pH}$. 

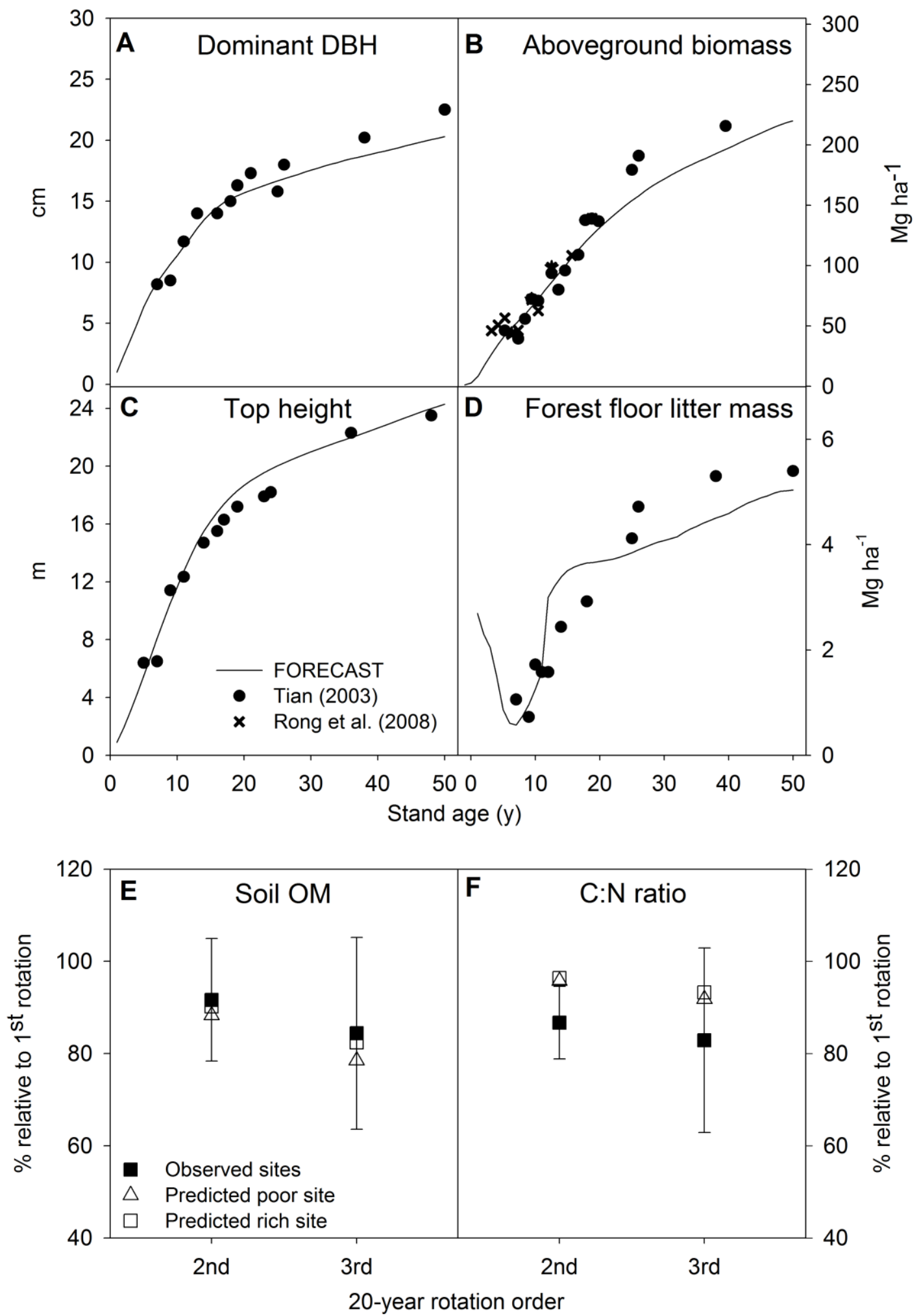

Figure 1. 

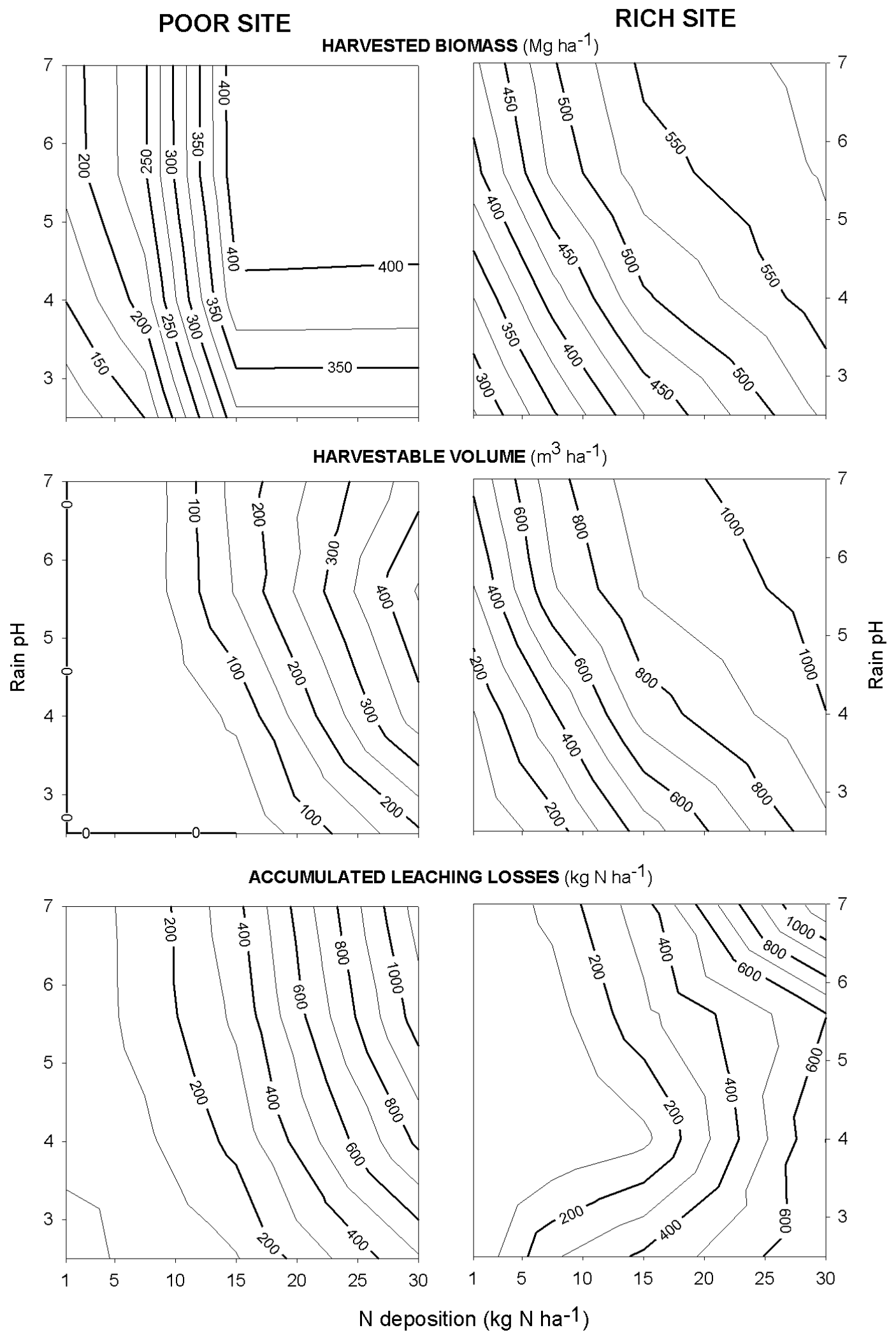

Figure 2. 


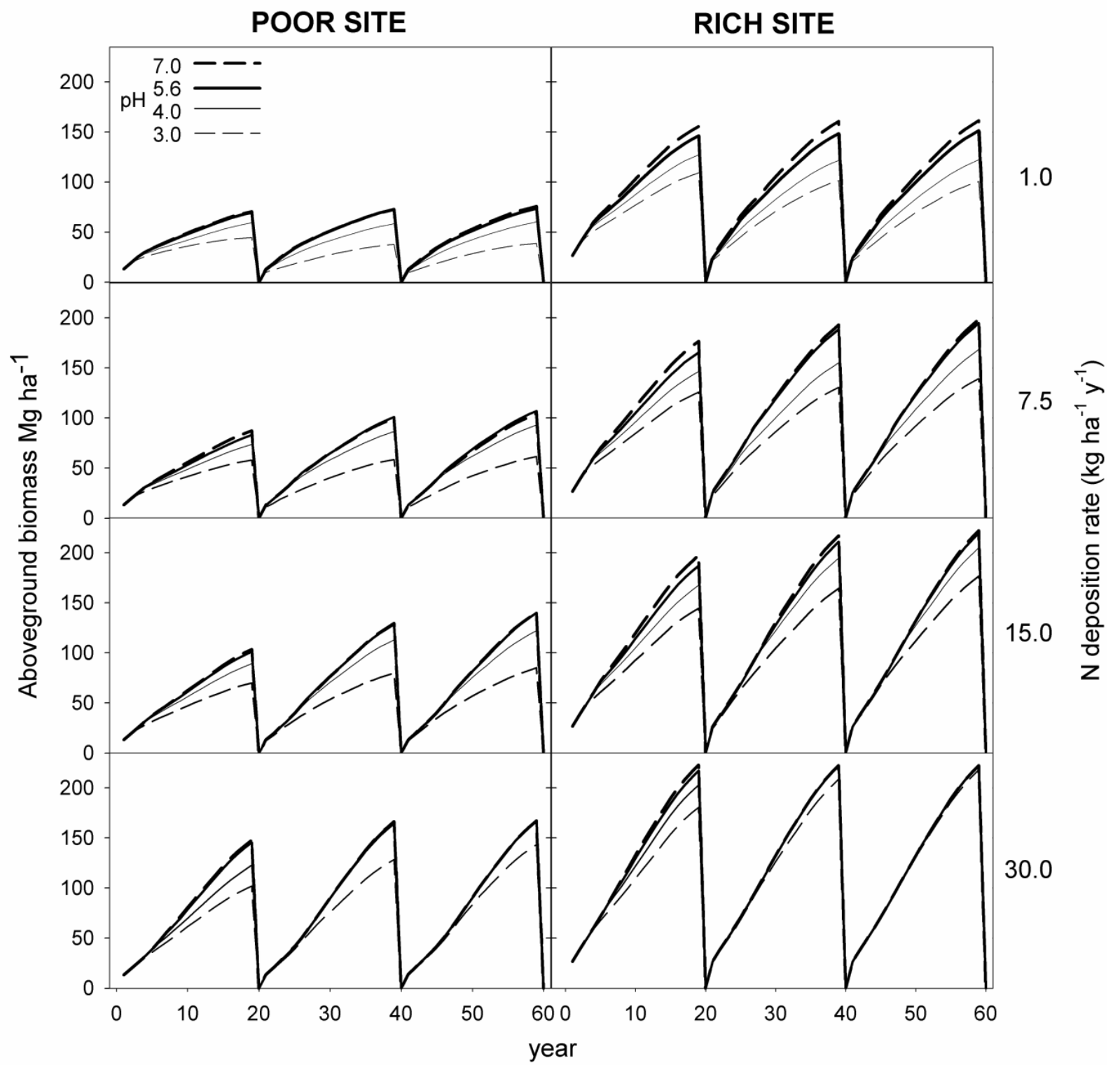

Figure 3. 


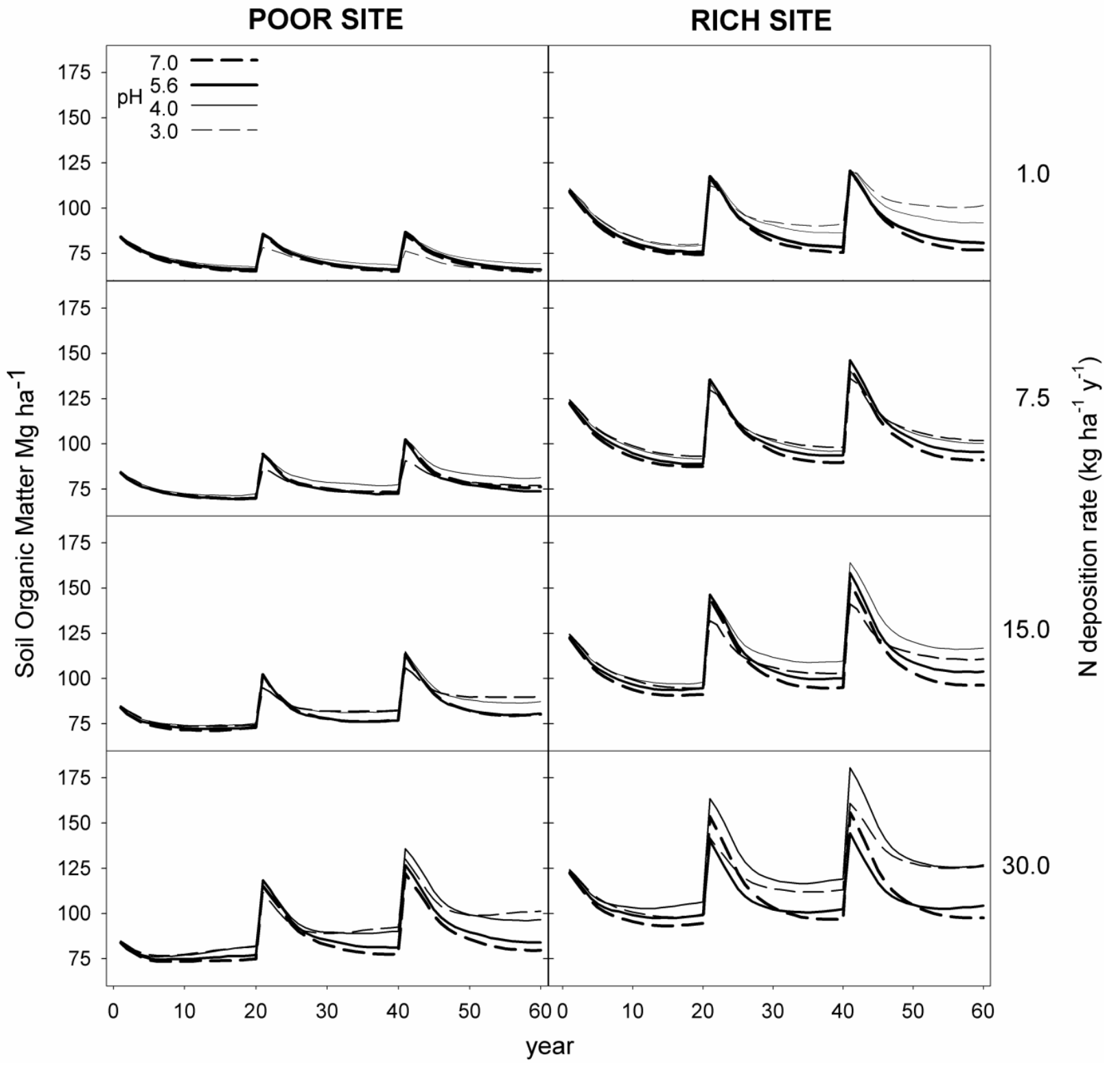

Figure 4. 


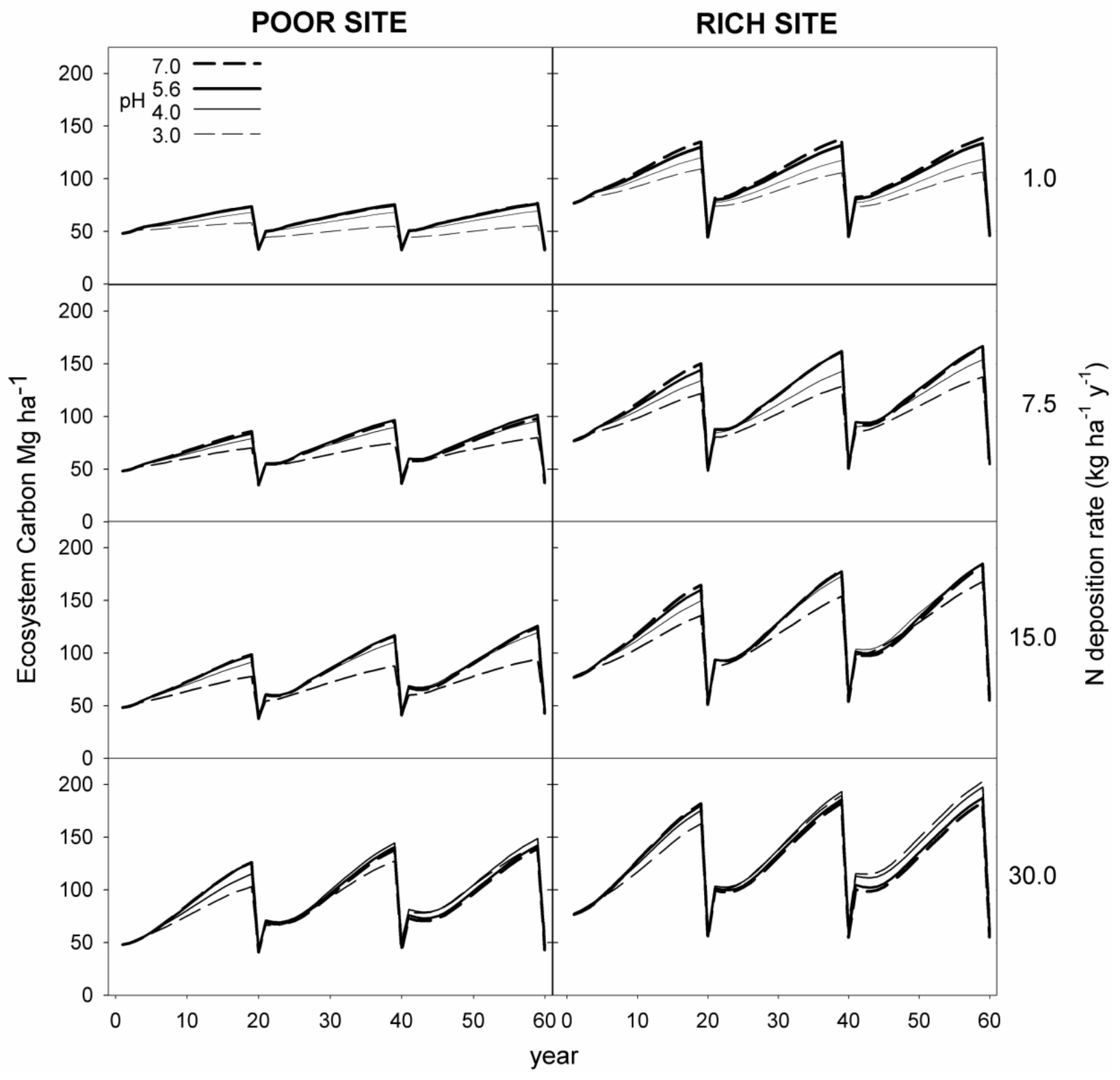

Figure 5. 


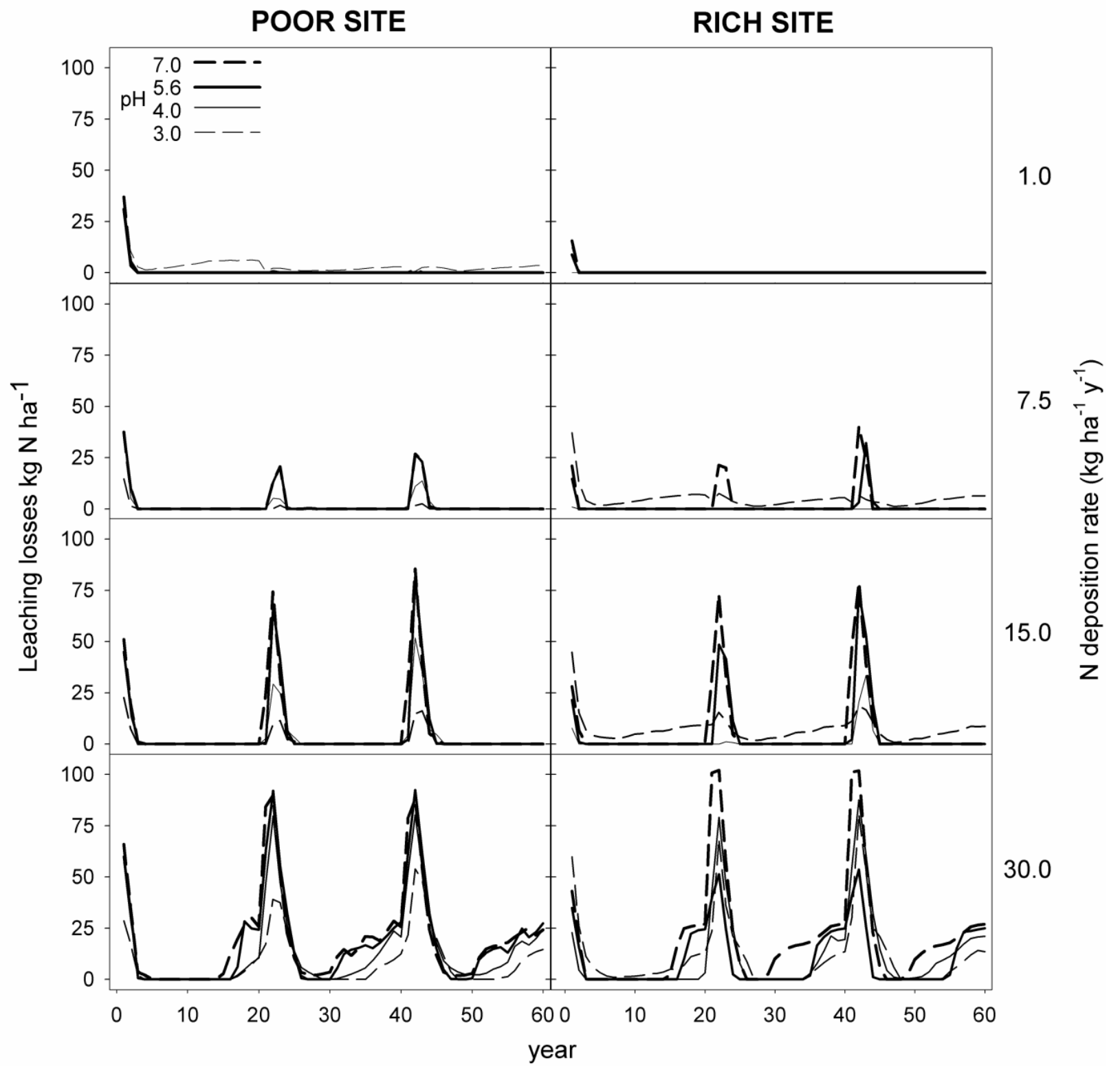

Figure 6. 